http://revped.ise.ro

Print ISSN 0034-8678; Online ISSN: 2559 - 639X

\title{
THE PERSPECTIVE AND THE EFFECTS OF ROBOTICS COURSES IN SCHOOL EDUCATION
}

\author{
PERSPECTIVA ŞI EFECTELE UTILIZĂRII CURSURILOR DE ROBOTICĂ ÎN \\ EDUCATIIA ŞCOLARILOR
}

\author{
Ana-Maria POPA \\ Journal of Pedagogy, 2019 (1), 175 - 187 \\ https://doi.org/10.26755/RevPed/2019.1/175
}

The online version of this article can be found at: http://revped.ise.ro/category/2019-en/

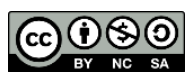

This work is licensed under the Creative Commons Attribution-NonCommercial-ShareAlike 4.0 International License. To view a copy of this license, visit http://creativecommons.org/licenses/by-nc-sa/4.0/ or send a letter to Creative Commons, PO Box 1866, Mountain View, CA 94042, USA.

Published by:

\section{INSTITUTUL DE ȘTIINȚE ALE EDUCAȚIEI}

http://www.ise.ro/

Further information about Revista de Pedagogie - Journal of Pedagogy can be found at:

Editorial Policy: http://revped.ise.ro/editorial-policy/

Author Guidelines: http://revped.ise.ro/the-writer-guide-2/ 


\title{
PERSPECTIVA ŞI EFECTELE UTILIZĂRII CURSURILOR DE ROBOTICĂ ÎN EDUCA IA ŞCOLARILOR
}

\author{
Ana-Maria Popa* \\ Universitatea din Bucureşti, \\ Facultatea de Psihologie şi Ştiin ele Educa iei, \\ Bucureşti, România \\ anamaria@eusuntoktuestiok.ro
}

\section{Rezumat}

Această cercetare s-a concentrat pe explorarea modului în care introducerea cursurilor de robotică în şcoală poate îmbunătă i procesul instructiv-educativ, în special în direc ia antrenării copiilor către abilită ile specifice secolului 21 , dar şi datorită roboticii care atrage din ce în ce mai mult. La această cercetare au participat două grupuri de elevi de la o şcoală de stat din Bucureşti: Şcoala Gimnazială Nr. 195. Grupul experimental a participat la cursul de Robotică şi grupul de control a participat la un curs de Matematică Aplicată în Transmiterea Mişcării, pe o perioadă de şapte săptămâni, în anul 2017. În momentul respectiv, elevii din ambele grupuri erau clasa a III-a, iar media lor de vârstă era de 9-10 ani. Grupul care a desfăşurat cursul de Robotică a fost compus din 33 elevi, iar grupul care a desfăşurat cursul de Matematică Aplicată în Transmiterea Mişcării a fost compus din 37 elevi.

Pentru această cercetare s-au utilizat kiturile furnizate de compania LEGO de tipul LEGO Mindstorm, acestea permi ând elevilor lucrul în echipă. Astfel, s-a facilitat în elegerea no iunilor de bază, iar copiii au reuşit ulterior să-şi exprime şi să-şi dezvolte ideile proprii. No iunile de robotică, conceptele tehnologice de bază au fost uşor asimilate de grupele de elevi cu media de vârstă 10 ani. Dezbaterile dintre elevi, rezolvarea problemelor matematice, munca în echipă, valorificarea interesului pe care copiii îl aveau pentru designul robo ilor, demonstrează că robotica este o disciplină ce câştigă teritoriu.

* Drd., Facultatea de Psihologie şi Ştiin ele Educa iei, Universitatea din Bucureşti, România. 
Cuvinte-cheie: copii, matematică, probleme, rezolvare, robotică.

\section{Abstract}

This research has focused on exploring how the introduction of robotics classes in school can improve the educational process, especially in the direction of teaching children with the abilities of the $21^{\text {st }}$ century, due to the new robotics that are attracting more and more. Two groups of students from a state school in Bucharest, Secondary School Nr. 195, participated in this research. The experimental group participated in the Robotics course and the control group participated in a course on Applied Mathematics in Transmission of the Movement, over a seven weeks period, in the year 2017. At that time, the students in both groups were in 3rd grade, their average ages was 9-10 years. The group that conducted the Robotics course had 33 students, and the group that developed the Applied Mathematics course in Transmitting the Movement had 37 students.

For this research, LEGO kits such as Lego Mindstorm have been used and assimilated, allowing students to work in teams. This facilitated the understanding of the basic notions, and the children subsequently succeeded in expressing and developing their own ideas. The notions of robotics, the basic technological concepts have been easily assimilated by groups of students aged 10. Student debates, mathematical problem solving, teamwork, and the interest of children in the process of designing robots shows that robotics is a winning discipline.

Keywords: children, math, problems, robotics, solution.

\section{Scopul şi semnifica ia cercetării}

Obiectivul principal al acestei cercetări exploratorii este acela de a observa procesul prin care copiii îşi formează abilită i tehnologice şi implementează solu ii la problemele întâlnite, atât pentru cele din sfera tehnologiei, cât şi pentru cele matematice, creându-se în felul acesta o finalitate imediată între teorie şi practică. Proiectarea acestui curs urmăreşte să observe dacă construirea robo ilor poate fi un mijloc pedagogic în procesul instructiv-educativ al elevilor din clasele primare. Studiul îşi propune să stabilească nivelul de atrac ie al copiilor în activitatea practică de design al robo ilor, să determine consecin ele pe care le are metoda rezolvării problemelor tehnologice asupra performan elor elevilor participan i la curs, dar şi să măsoare gradul de schimbare a percep iei părin ilor elevilor participan i la cele două cursuri, înainte şi după finalizarea lor. 
Datorită faptului că tot mai mul i părin i aleg să-şi înscrie copiii la cursuri de robotică, dar şi pentru că cercetările academice pe această temă sunt destul de rare, în momentul actual un studiu care să măsoare efectele roboticii în dezvoltarea şi educa ia copiilor este binevenit. De asemenea, această cercetare exploratorie îşi propune să observe partea pozitivă a utilizării tehnologiei de către copii, atât din punctul de vedere al dezvoltării cognitive, dar şi sociale (DePorter, 2001).

\section{Programul Lego Mindstorm}

Cu ajutorul acestui kit de tip Lego Mindstorm, copiii înva ă lucruri referitoare la modurile de transmitere a mişcării, construind robo ei care se deplasează cu ajutorul bateriilor şi motoarelor Lego. Copiilor li se prezintă şi li se explică teme din domeniile ştiin ei, tehnologiei şi matematicii prin utilizarea jocurilor şi modelelor aplicative (Robinson, 2005). Acest curs nu vizează doar distrac ia, ci şi îmbogă irea cunoştin elor, dezvoltarea gândirii şi a creativită ii. Procesul de învă are este sus inut de calculator. Această nouă abordare face ca procesul de construc ie a diferitelor mecanisme să fie mai atractiv şi îi ajută pe copii să îşi dezvolte orientarea în spa iu. După efectuarea fiecărei etape a construc iei, softul instalat pe calculator permite rotirea modelului la 360 grade, astfel încât copiii să poată descoperi fiecare detaliu al mecanismului şi să poată studia cu uşurin a interac iunea şi legăturile dintre piesele componente. (http://mindstormes.lego.com/)

\section{Rezolvarea problemelor şi tehnologia}

Folosirea elementelor de tehnologie ca mijloc de rezolvare a problemelor matematice a căpătat din ce în ce mai mult teritoriu, popularitate şi importan ă odată cu apari ia calculatoarelor performante şi a diverselor aplica ii. În prezent, există jocuri video care le oferă copiilor diverse modalită i de a în elege o problemă şi de a elabora strategii de rezolvare (Wegerif, 2002). Un procedeu prin care profesorii pot înlesni abilită ile elevilor de a rezolva problemele este acela de a-i îndruma pe aceştia să nu se orienteze pe rezultate, ci pe procese. În cartea Mindfulness, apărută la New York în 1989, Ellen Langers a dezbătut această problemă, autoarea îndemnând cadrele didactice 
să-i încurajeze pe elevi să se orienteze asupra modului în care pot rezolva o anumită problemă, şi nu să piardă timp pre ios gândindu-se dacă pot ajunge la rezultatul corect (Langers, 1989). Pu in mai târziu, un alt psiholog american, William Huitt, vorbea în lucrarea Critical thinking: An overview despre puterea creativită ii pe care o demonstrează persoanele care arată că se descurcă în rezolvarea problemelor matematice, el numind creativitatea ca fiind un mijloc deosebit de rezolvare a problemelor. Astăzi, persoanele despre care se spune că au succes atât în via a personală, cât şi în cea profesională, pot fi caracterizate ca persoane care îşi pun şi identifică probleme, explorează rezolvări variate, folosesc adecvat strategii de gândire, antrenând în felul acesta întregul proces metacognitiv (Huitt, 1999).

În lucrarea Blocks to robots: Learning with technology in the early childhood classroom (2008), Bers scria că deşi este esen ial să se ofere oportunită i de învă are studen ilor pentru a crea proiecte tehnologice, bazate pe ideile şi interesele acestora, în anumite situa ii, chiar dacă ideile lor sunt inovatoare, acestea se pot pierde fără o îndrumare adecvată şi fără un plan concret. Acest lucru se întâmplă, pentru că este posibil că ei să nu aibă încă formată abilitatea de a face ca propriile idei să capete via ă. Pentru învă area bazată pe proiect, în special, în cazul elevilor şi studen ilor neexperimenta i, un aspect important este construc ia scenariului de lucru. În mediul de lucru al învă ării bazate pe proiect, rolul profesorului este esen ial, acesta devenind un mediator sau facilitator al echipei (Bers, 2008).

\section{Metodologie}

În prezentul studiu, accentul a fost pus pe stilurile de solu ionare a problemelor tehnologice şi pe performan a atinsă de către elevi în cadrul cursului de robotică. Cursul s-a desfăşurat pe parcursul a şapte săptămâni. S-au folosit instrumente de cercetare precum: chestionare pre-test şi post-test, atât pentru elevi, cât şi pentru părin ii acestora, câte 15 interviuri la fiecare grupă şi observa ii consemnate la sfârşitul fiecărui curs de către to i elevii. Chestionarele au fost aplicate la începutul şi la sfârşitul cursului atât elevilor, cât şi părin ilor acestora. La această cercetare au participat două grupuri de elevi: grupul experimental a participat la cursul de Robotică şi grupul de control a participat la un curs de Matematică Aplicată în 
Transmiterea Mişcării. Elevii din ambele grupuri erau clasa a III-a, iar media lor de vârstă era de 9-10 ani. Grupul care a desfăşurat cursul de Robotică a avut 33 elevi, iar grupul care a desfăşurat cursul de Matematică Aplicată în Transmiterea Mişcării a avut 37 elevi.

Înainte de începerea cursurilor a fost ob inută aprobarea administrativă a şcolii şi cea a părin ilor.

\subsection{Metodele utilizate}

Studiul a adoptat o metodologie mixtă, atât cantitativă cât şi calitativă, cu scopul de a expune cât mai multe aspecte ale procesului de învă are, în mod special gândurile şi ac iunile copiilor în rela ie cu munca din cadrul proiectului şi sentimentele dobândite de elevi.

Elevii au completat aceleaşi chestionare la începutul şi sfârşitul cursului desemnat primului grup, experimental (în Robotică) şi a celuilalt grup, de control (în Matematică Aplicată în Transmiterea Mişcării) într-un număr egal de expresii. Părin ii elevilor au completat şi ei chestionare înainte de începerea cursului şi după finalizarea lui. Chestionarele adresate părin ilor vizează încrederea în curs şi efectele asimilării cunoştin elor tehnologice şi ştiin ifice observate la copii în timpul şi după finalizarea cursului. Semnifica ia diferen ei medii între fiecare din cele două grupe a fost examinată.

În acest studiu de cercetare, pentru chestionarele adresate părin ilor a fost utilizată scala Likert pe 5 niveluri unde: $1=$ sunt deplin de acord, $2=$ sunt de acord în linii mari, $3=$ am o părere oarecum diferită, $4=$ nu sunt în general de acord, $5=$ nu sunt deloc de acord. Pentru chestionarele adresate elevilor s-a utilizat scala Guttman pe două niveluri: cu răspunsuri de tipul $\mathrm{Da} / \mathrm{Nu}$.

Această cercetare este în primul rând centrată pe procesele de lucru ale elevilor, pe modelele realizate de ei şi pe reflec ia pe care au avut-o lucrările lor asupra cursului. Strângerea datelor a avut ca scop urmărirea activită ilor elevilor în sala de clasă, felul în care au abordat temele în mod individual şi în echipă, procesele de completare a sarcinilor trasate şi textele expunerilor pe care le-au pregătit spre prezentare în clasă. 


\subsection{Analiza datelor}

În prima etapă, datele au fost introduse în programul computerizat Excel, iar apoi, în a doua etapă, datele statistice au fost transferate pentru analiză într-un program de statistică. Pentru a demonstra cât mai multe fa ete posibile ale procesului de învă are, în mod deosebit a sentimentelor şi gândurilor elevilor fa ă de munca lor, cercetarea a adoptat şi o metodologie calitativă. Colectarea datelor a avut ca scop observarea activită ilor elevilor în clasă, felul lor de a participa la sarcinile de lucru în mod individual şi în echipă. Toate aceste date au fost colectate prin completarea unui jurnal al clasei la sfârşitul fiecărei şedin e de lucru.

\subsection{Ipoteza şi variabilele cercetării}

Ipoteză: Dacă elevii participă la cursul de Robotică, atunci aceştia vor da dovadă de un grad de implicare şi motivare mai mare în participarea la activită i fa ă de elevii care participă la cursurile de Matematică Aplicată în Transmiterea Mişcării.

\section{Variabile:}

Independente: participarea elevilor la cursul de Robotică sau la cel de Matematică Aplicată în Transmiterea Mişcării.

Dependente: gradul de implicare şi motiva ia elevilor implica i. Studiul se axează pe răspunsul la următoarele întrebări:

1) Pot fi găsite diferen e în dezvoltarea motiva iei de învă are a matematicii pe parcursul desfăşurării celor două cursuri?

2) Dau dovadă elevii participan i la cursul de Robotică de un grad mai mare de implicare şi entuziasm în rezolvarea sarcinilor de lucru?

3) Părin ii elevilor participan i la cursuri observă efecte pozitive de comportament şi rela ionare ale copiilor în timpul şi după finalizarea cursurilor. Dacă da, care din cele două cursuri este mai productiv, din acest punct de vedere? 


\section{Interpretarea calitativă şi cantitativă a datelor}

\subsection{Interpretarea calitativă a datelor}

La ambele grupe, atât cel de Robotică, cât şi cel de Matematică Aplicată în Transmiterea Mişcării, s-a inut, pe parcursul celor 7 săptămâni de curs, un jurnal al clasei în care elevii şi-au notat impresiile despre curs, ce au învă at şi ce le-a plăcut din con inutul şi modul de desfăşurare a fiecărui curs în parte. Jurnalul s-a inut atât în forma individuală, cât şi colectivă. La sfârşitul cursurilor, elevilor li s-au luat scurte interviuri care au vizat observarea atingerii obiectivelor cursurilor. Din interpretarea datelor din jurnale/ interviuri, s-au putut extrage următoarele concluzii:

- Copiii aşteptau cu mai mult interes şi entuziasm desfăşurarea cursului de Robotică decât a celui de Matematică Aplicată în Transmiterea Mişcării.

- Din datele jurnalelor copiilor s-a observat o mai mare motiva ie şi plăcere a elevilor de la Robotică de a participa la următorul curs, decât a elevilor care participau la cursul de Matematică Aplicată în Transmiterea Mişcării.

- Nu s-au semnalat absen e şi întârzieri la cursul de Robotică, în schimb la cursul de Matematică Aplicată în Transmiterea Mişcării, 10 din cei 37 copii au avut cel pu in o absen ă şi s-au semnalat şi întârzieri la curs, având în vedere că cele două ore s-au inut în afara programului obligatoriu de şcoală.

- Copiii au prezentat un grad mai mare de curiozitate în cadrul cursului de Robotică. Această constatare a putut fi observată prin frecven a întrebărilor pe care copiii le puneau profesorilor, dar şi prin timpul alocat acasă documentării suplimentare despre temele cursurilor. 20 dintre cei 33 copii participan i la cursul de Robotică au declarat că au urmărit acasă filmule e despre Lego Mindstorm, pe când doar 5 dintre cei 37 copii participan i la cursul de Matematică Aplicată în Transmiterea Mişcării au declarat că au pus întrebări părin ilor despre mecanismele de transmitere de la diferite aparate sau au căutat pe internet informa ii suplimentare despre mişcare şi mecanismele ei.

- La finalul celor două cursuri au fost intervieva i câte 7 părin i ai elevilor participan i la ambele cursuri. To i cei 7 părin i ai copiilor participan i la cursul de Robotică au afirmat că au sesizat la elevi entuziasm şi interes atunci când povesteau acasă despre curs, iar 3 din cei 7 au declarat că au 
achizi ionat câte un robot de tip Lego Mindstorm, astfel încât copiii să poată exersa şi acasă ce înva ă la şcoală. În schimb, 4 din cei 7 părin i ai copiilor participan i la cursul de Matematică Aplicată în Transmiterea Mişcării au afirmat că au sesizat la propriii copii sentimentul că percep ca pe o obliga ie participarea la curs.

- Chiar dacă programul Lego se prezintă ca unul de construc ie şi design, deseori copiii care au participat la cursul de Robotică şi-au proiectat în timpul liber diverse modele de robo ei, pe care i-ar fi putut construi cu ajutorul pieselor din kit. În timpul cursului, ei şi-au împărtăşit ideile cu ceilal i colegi din echipă. Aşadar, munca de echipă în proiectarea şi designul robo ilor a întărit rela iile de colegialitate şi socializare dintre membrii echipei.

\subsection{Interpretarea cantitativă a datelor}

\subsubsection{Comentarii legate de cele două grupuri de copii în func ie de} elementele comune/diferite referitoare la cele două tipuri de cursuri

În ceea ce priveşte aşteptările copiilor legate de cursul de Matematică Aplicată în Transmiterea Mişcării (CMATM), dacă înainte de începutul acestuia, 32 afirmau că le-ar plăcea să participe la un astfel de curs, la final, doar 17 afirmau că acesta le-a plăcut. Comparativ, aşteptările copiilor legate de cursul de robotică nu s-au modificat în intervalul început de curs/final de curs, to i cei 33 de copii afirmând că le-ar plăcea şi că, într-un final, le-a plăcut acest curs. Acest element ar putea constitui un prim indiciu care eviden iază diferen a dintre modul în care cele două tipuri de cursuri au ac ionat asupra cunoştin elor şi raportărilor copiilor.

În cazul CMATM, participarea copiilor la acesta nu a modificat substan ial atitudinile lor fa ă de capacitatea de a-şi aduce contribu ia la proiecte sau în ceea ce priveşte posibilitatea de a aplica no iunile de matematică învă ate la curs în afara şcolii, ratând unul din principalele obiective ale cursului şi anume construirea unei rela ii între aspectele teoretice şi modalitatea în care acestea pot fi aplicate. Cu toate acestea, se constantă că un aspect pozitiv al CMATM este acela că percep ia copiilor referitoare la cunoaşterea mecanismelor care stau la baza transmiterii mişcării a crescut (de la 23 de 
copii care cunoşteau aceste mecanisme înaintea cursului, până la 32 după finalizarea sa); acelaşi lucru putându-se afirma şi în cazul în elegerii faptului că transmiterea mişcării sau proiectarea unui mecanism nu se poate face fără cunoaşterea no iunilor de matematică (percep ia modificându-se de la 22 de copii care considerau la începutul cursului că e important să cunoşti no iuni de matematică pentru a în elege modul în care se produce transmiterea mişcării, până la 30 la final; respectiv de la 23 de copii care considerau la începutul cursului că e important să cunoşti no iuni de matematică pentru a proiecta lucruri, până la 36 la finalul lui). Aceste elemente par a fi în concordan ă cu asump ia privind capacitatea teoretică explicativă ridicată a modelelor matematice prezentate la CMATM. Cu toate acestea, parcurgerea cursului nu oferă cifre îmbucurătoare în ceea ce priveşte capacitatea lui de a dezvolta competen e practice în rândul copiilor. În acest sens, se observă că acesta nu a reuşit să inducă ideea conform căreia există posibilitatea de a aplica no iunile teoretice învă ate în sala de clasă asupra unor situa ii din via a reală - ba din contră, parcurgerea cursului pare că a dus la întărirea unei convingeri contrare. Dacă la începutul cursului 25 de copii credeau că ceea ce înve i în clasă nu se poate aplica unor situa ii reale, la finalul acestuia, contrar aşteptărilor asumate de obiectivele cursului, 29 de copii au ajuns la această concluzie. Situa ia este complet diferită în cazul copiilor care au parcurs cursul de robotică. Dacă la începutul acestuia, 17 credeau că nu pot aplica no iunile de matematică învă ate la şcoală în via a reală, la finalul lui doar 10 mai aveau această opinie. În acest sens, se întăreşte un trend care este în concordan ă cu unul din obiectivele asumate ale cursului şi anume crearea unei pun i între teorie şi practică.

Referitor la posibilitatea de a în elege mai uşor cum se rezolvă problemele de matematică dacă ar exista o legătură între acestea şi modul în care func ionează jucăriile, cu toate că la începutul CMATM, 36 de copii considerau că dacă ar exista această legătură ar putea învă a mai uşor, până la finalul cursului, doar 32 dintre ei mai afirmau acest lucru. Această situa ie poate fi determinată de o dezamăgire pe care copiii care au participat la CMATM au avut-o la finalul acestuia, aşteptările lor personale legate de rezultatele cursului neconcordând cu ceea ce s-a întâmplat la final. Un alt minus al CMATM, comparativ cu cursul de robotică, este reprezentat şi de incapacitatea de a întări rela iile dintre colegi, pentru că la finalul cursului, 18 dintre copiii participan i au declarat că acest curs nu a atins acest obiectiv. 
Se poate astfel afirma că participarea la cursul de Matematică Aplicată în Transmiterea Mişcării le-a modificat percep ia copiilor în ceea ce priveşte capacitatea de a lucra în echipă într-o mică măsură. Dacă la începutul cursului, 28 de copii afirmau că ar lucra mai bine de unii singuri, la final doar 23 mai afirmau acest lucru, iar dacă la începutul cursului doar un singur elev afirma că lucrul în echipă nu te ajută să rezolvi problemele de matematică, la final doar 10 dintre ei afirmau acest lucru.

În ceea ce priveşte cursul de Robotică, conform datelor statistice, reiese că elevii care 1-au parcurs şi-au modificat percep iile într-un sens mai apropiat de obiectivele asumate de acesta. De exemplu, la întrebarea „dacă imprimanta clasei este un robot", s-a constatat că dacă la începutul cursului, 13 dintre elevi afirmau că „da, aceasta este un robot”, după parcurgerea lui, doar 2 nu mai afirmau acest lucru. Acest aspect reprezintă un indicator al modului în care cursul le-a modificat copiilor imaginea despre ceea ce înseamnă un robot şi care sunt caracteristicile care îl definesc. Unul dintre cele mai importante aspecte ale cursului de robotică este acela că (contrar rezultatelor ob inute în cazul copiilor care au parcurs CMATM) a reuşit să întărească capacitatea elevilor de a lucra în echipă, 24 dintre copii afirmând la sfârşitul cursului că nu ar lucra mai bine singuri atunci când trebuie să construiască robo i, spre deosebire de începutul cursului, moment în care doar 9 considerau acest lucru.

\subsubsection{Comentarii legate de atitudinile/părerile părin ilor din cele două} grupuri

În ceea ce priveşte percep ia părin ilor copiilor care au făcut CMATM, aceştia consideră, la finalul cursului, că acesta a avut efecte pozitive asupra copiilor într-o măsură mai mică decât aşteptările pe care le aveau la început. Dacă la începutul cursului 29,7\% dintre ei erau de acord în linii mari, iar 70,3\% considerau că au o părere oarecum diferită despre efectul cursului, la final, 29,7\% migraseră dinspre „am o părere diferită” spre răspunsul mult mai categoric „nu sunt în general de acord că acesta va avea efecte pozitive asupra copilului”. În ceea ce priveşte percep ia părin ilor copiilor care au făcut cursul de Robotică, din punct de vedere comparativ, se poate observa o diferen ă majoră. Dacă la începutul lui, 89,3\% considerau că sunt de acord 
în linii mari că acesta va avea efecte pozitive asupra copiilor, la final, 96,4\% erau de această părere. În schimb, datele sunt oarecum contradictorii atunci când ne raportăm la capacitatea CMATM de a dezvolta gândirea analitică abstractă a copiilor. Dacă la începutul cursului, 27\% dintre părin i considerau că nu sunt în general de acord cu această afirma ie, la final niciunul dintre ei nu mai continua să aibă această părere. Cu toate acestea, faptul că 44,1\% dintre părin i considerau la finalul cursului că au o părere oarecum diferită în ceea ce priveşte capacitatea CMATM de a dezvolta gândirea analitică abstractă a copiilor, acest fapt reprezentând un procent mult mai mare comparativ cu cei $8,1 \%$ care dădeau acest răspuns înainte de începerea lui. În ceea ce priveşte percep ia părin ilor privind capacitatea cursului de Robotică de a dezvolta abilită ile legate de rezolvarea problemelor de matematică ale copiilor, acestea sunt oarecum constante în rândul părin ilor, observându-se totuşi o mică schimbare a procentelor la finalul cursului dinspre „, sunt de acord în linii mari” - 78,6\% către $64,9 \%$ şi , am o părere oarecum diferită” de la 17,9\% spre 32,4\%, reliefând o aparentă neatingere a aşteptărilor părin ilor fa ă de curs în ceea ce priveşte această temă.

S-a observat că CMATM nu a reuşit să modifice, în sensul obiectivelor stabilite, părerea părin ilor în ceea ce priveşte capacitatea lui de a-i face pe copii să în eleagă şi să asimileze mai uşor no iunile de tehnologie. În acest sens, la finalul cursului, 27,6\% dintre părin i considerau că nu sunt deloc de acord cu capacitatea acestuia, în condi iile în care la începutul lui, niciunul nu îşi exprima această părere. În ceea ce priveşte părerile părin ilor copiilor care au parcurs cursul de Robotică pe această temă, s-au modificat în sensul obiectivului asumat de curs. Dacă la începutul lui, 78,6\% dintre părin i erau de acord în linii mari că acest curs va atinge acest obiectiv, la final, numărul lor a crescut până la 89,2\%. Cifre mai bune ob ine CMATM la capitolul „capacitatea de dezvoltare a creativită ii copiilor”. Dacă la începutul cursului, 45,2\% dintre părin i considerau că nu sunt deloc de acord că acest curs va reuşi acest lucru, la final doar 5,4\% mai erau de această părere. Acelaşi trend pozitiv se poate observa şi în cazul părin ilor copiilor care au trecut prin cursul de robotică. Dacă la începutul acestuia, 77,8\% considerau că sunt de acord în linii mari cu capacitatea cursului de a le dezvolta copiilor creativitatea, la finalul lui, 94,6\% erau de această părere. De asemenea, se mai observă şi că percep ia părin ilor referitoare la rolul CMATM în implicarea lor în procesul de învă are a scăzut în intervalul 
începutul cursului - finalul cursului, ajungându-se ca la final 29,7\% dintre ei să considere că nu sunt deloc de acord cu ideea că acest curs ar fỉ reuşit să atingă acest obiectiv. În schimb, se observă că în cazul percep iei părin ilor copiilor care au trecut prin acest curs, trendul este unul mai degrabă în favoarea ideii că acest curs a reuşit să crească nivelul de implicare al părin ilor în procesul de învă are.

\section{Concluzia studiului}

În contextul actual al învă ământului românesc, un curs de Robotică, adaptat vârstei copiilor, este capabil să motiveze copiii să înve e nu doar elemente solide de tehnologie, dar şi de matematică. Atrac ia copiilor spre lucrurile pe care le pot pune în mişcare, dorin a de a-şi construi propriile jucării într-o modalitate naturală, le poate produce acestora, fără să-şi dea seama, un progres intelectual remarcabil. Un curs de Robotică poate fi un puternic instrument de dezvoltare a creativită ii şi inteligen ei, mai ales in educa ia de azi din şcoli, când copiii înva ă cu ajutorul gadgeturilor. Cursurile de Robotică au poten ialul de a crea abilită i necesare elevului pentru a avea succes în lumea reală de astăzi. Pasiunea de a răspunde la provocările prezentului este impulsul care îi mobilizează pe unii profesori să introducă în sala de clasă şi robotica educa ională. Profesorii/mentorii trebuie să ină cont că unul dintre rolurile pe care le au la clasă este de a-i provoca pe elevi să fie creativi şi cât mai inovativi în rezolvarea problemelor.

Robotica reprezintă un aspect pozitiv a influen ei tehnologiei în rândul copiilor şi are şanse şi argumente de a putea fi urcată la rangul de disciplină în şcoala contemporană şi modernă.

\section{Referin e}

- DePorter, B. (2001). Accelerated Learning. New Horizons for Learning. Accesat la: www.newhorizons.org

- Theory in the constructivist debate. Educational Psychologist, 31(3/4), 163174. 
- Huitt, W. (1998). Critical thinking: An overview. Valdosta, GA: Valdosta State University.

- Bers, M.U. (2008). Block to Robots: Learning with technology in the early childhood classroom. New York, NY: Teachers College Press.

- Langer, E. J. (1989). Mindfulness. New York: Merloyd Lawrence.

- Papert, S. (1980). Mindstorms: Children, computers, and powerful ideas. New York: Basic Books Inc.

- Papert, S., \& Harel, I. (1991). Constructionism. Norwood, NJ: Ablex.

- Robinson, M. (2005). Robotics-driven activities: Can they improve middle school science learning? Bulletin of Science. Technology \& Society, 25(1), 7384.

- Rogers, C., \& Portsmore, M. (2004). Bringing engineering to elementary school. Journal of STEM Education, 5(3\&4), 17-28.

- Wegerif, R. (2002). Literature review in thinking skills, technology, and learning. Bristol, England: NESTA, 2002. Accesat la: www.nestafuturelab.org/research/ reviews/ts01.htm

- http://mindstormes.lego.com/

The online version of this article can be found at: http://revped.ise.ro/category/2019-en/

\section{(CC) $\mathrm{B} Y-\mathrm{NC}-\mathrm{SA}$}

This work is licensed under the Creative Commons Attribution-NonCommercial-ShareAlike 4.0 International License.

To view a copy of this license, visit http://creativecommons.org/licenses/by-nc-sa/4.0/ or send a letter to Creative Commons, PO Box 1866, Mountain View, CA 94042, USA
Versiunea online a acestui articol poate fi găsită la: http://revped.ise.ro/category/2019-ro/

\section{(cc) BY-NC-SA}

Această lucrare este licen iată sub Creative Commons Attribution-NonCommercial-ShareAlike 4.0 International License.

Pentru a vedea o copie a acestei licen e, vizita $i$ http://creativecommons.org/licenses/by-nc-sa/4.0/ sau trimite i o scrisoare către Creative Commons, PO Box 1866, Mountain View, CA 94042, SUA. 